\title{
INVESTIGATING THE EFFECT OF MINERAL NUTRITION AND LIGHT QUALITY ON SOME GROWTH-RELATED METABOLITES AND PIGMENTS OF TWO FILAMENTOUS CYANOBACTERIA (CYANOPROKARYOT)
}

\author{
Nermin Adel El Semary ${ }^{1}$, Safia Ghazy ${ }^{1}$, Abou El Kheir Badawy ${ }^{2}$, \\ Mohamed El Fouly ${ }^{2}$ and Mohamed Hassoub ${ }^{2}$ \\ 1- Department of Botany and Microbiology, Faculty of Science, Helwan \\ University, Helwan, Egypt \\ 2- Fertilization Technology Department, National Research Centre, Dokki, \\ Cairo, Egypt
}

\begin{abstract}
The effect of mineral nutrition on growth-related metabolites and pigmentation of the filamentous Anabaena flos-aquae and Calothrix sp. PCC7601 was investigated. Key nutrients (iron, phosphorus and nitrogen) were supplied at different concentrations compared to original BG-11 growth medium. The results showed general increase of peptide nitrogen and total sugars, chlorophyll $a$ content and phycobiliprotein pigments content with the use of double concentration of different key nutrients. The opposite was observed for most of these parameters under half and quarter the concentration of nutrients tested in both isolates. Meanwhile, carotenoids increased under half the concentration of iron and phosphorus compared to the original concentrations of BG-11 medium but decreased at quarter concentrations of the original BG-11 medium. The effect of nitrogen limitation on growth and pigments content on A. flos-aquae was overly less severe due to the ability of A. flos-aquae to compensate for limited supply of available nitrogen through nitrogen fixation. At all reduced concentrations of key nutrients, phycoerythrin pigment predominated other phycobiliprotein pigments under white light in Calothrix sp. To further investigate the effect of mineral nutrition and light quality on phycobiliprotein pigment composition, both isolates were grown under green and red monochromatic light. The highest content of phycroerythrin pigment was recorded under green light in both isolates under different nutrients treatments. Phycocyanin, on the other hand, predominated other phycobiliprotein pigments in most of nutrients treatments placed under red light in Calothrix sp. This strain was more responsive in terms of alternating its phycobiliprotein composition than A. flos aquae in response to different nutrients concentration and change in light quality. Thus, this isolate seems to be a promising source for those pigments production. The study shows that growth manipulation using different nutrients concentrations and light qualities can result in differential expression of the phycobiliprotein pigments in some cyanobacterial strains. This can be used for mass production of these valuable pigments for biotechnological applications.
\end{abstract}


Key words: Allophycocyanin, Carbohydrate, Carotenoids, Chlorophyll, Chromatic Adaptation, Growth, Phycocyanin, Phycoerythrin, Protein.

\section{Introduction}

Cyanoprokaryot are prokaryotic algae that are widespread in different water bodies around the globe (Whitton and Potts, 2006). They possess chlorophyll $a$, the primary light-harvesting pigment, thus performing oxygenic photosynthesis similar to plants and eukaryotic algae. However, they possess peptidoglycan cell wall and lack true nucleus and membrane-bound organelles, including plastids, thus possessing the ultrastructure of Eubacteria and were classified accordingly (Stanier and Cohen, 1977).

The cyanobacterial pigments are mainly chlorophyll $a$, carotenoids and phycobiliproteins. The latter are water-soluble blue or red accessory pigments located on thylakoids in special structures called phycobilisomes. The phycobilisome is an ultrastructure consisting of pigmented proteins (phycobiliproteins) as well as non-pigmented (linker) polypeptides (Glazer, 1994). They function as accessory pigments and absorb light at different regions within the spectrum; the blue phycocyanin $(\max 620 \mathrm{~nm})$ and allophycocyanin $(\max$ $650-670 \mathrm{~nm})$ and the red phycoeythrins ( $\max 550-570 \mathrm{~nm})$ (Fay, 1983). The phycobiliproteins are currently attracting attention as a source of fabric dyes (Kimura, 1995), as natural safe food colorants (Dufosse et al., 2005), and as antitumour substances (Bei $\boldsymbol{e t}$ al., 2002). They are already being used in many industrial applications due to their spectral properties (Sekar and Chandramohan, 2008).

Environmental conditions in general are known to affect pigment composition but the supply of key nutrients (e.g. nitrogen, phosphorus and iron) in particular is essential for cyanobacterial growth, thylakoid formation and pigment synthesis (Eng-Wilmont and Martin, 1977). Phycobiliprotein synthesis is particularly susceptible to nutrients limitation (Eng-Wilmont and Martin, 1977). For example, the effect of nitrogen deficiency on Pseudanabaena sp. and Oscillatoria splendida was investigated by De Loura et al. (1987), who found that nitrogen deficiency during growth caused a complete loss of phycocyanin, with no considerable change in the chlorophyll- $a$ content. The carotenoids: chlorophyll- $a$ ratio on the other hand, increased with nitrogen deficiency as similarly found by Datz and Dohler (1981) on Synechococcus. Hardie et al. (1983) reported that the cyanobacterium A. quadruplicatum, when grown under iron deficiency, underwent a break down of the phycocyanin pigment shortly after the growth rate dropped in response to iron deprivation as it represents a relatively dispensable nitrogenous compound.

Pigment composition is also affected by the intensity (photon flux density) and quality (spectral composition) of light, and the resulting changes in pigments enable the most efficient utilization of available light energy. This 
phenomenon is called "Complementary Chromatic Adaptation" where change in pigmentation is largely attributable to a change in the phycocyanin: phycoerythrin ratio (Bennett and Bogard, 1973). Phycoerythrin synthesis occurs at maximum rate in green light and is reduced or completely suppressed in red light. Phycocyanin synthesis in some species is independent of the spectral composition of light, in others it may be under chromatic control, occurring at maximum rate in red light and at its lowest rate in green light (Fay, 1983). This is a characteristic adaptation of some members of cyanobacteria including Calothrix (Bennett and Bogard, 1973) and Anabaena sp. (Fay, 1983). Unfortunately, not much is known about the effect of different essential nutrients concentrations on pigment composition at different light qualities. Since the commercial production of these pigments must take into account the cost of components of growth media as well as the growth conditions.

Therefore, the current study aims to test the different nutrients levels and select the treatments that would result in maximum pigment production with economic nutrient utilization for future exploitation.

\section{Materials and Methods}

\section{Organisms under study and culture conditions}

Anabaena flos-aquae, freshwater heterocystous unbranched filamentous cyanobacterium and Calothrix sp. PCC7601 were obtained from Bristol Culture Collection (Courtesy of Professor Paul Hayes, former Head of the School of Biological Sciences, University of Bristol, UK). Calothrix sp. PCC7601 was originally imported from Pasteur Culture Collection, Paris, France. A. flos-aquae was optimally grown at $18^{\circ} \mathrm{C}$ under light intensity of $20 \mu \mathrm{mol}$ photon $\mathrm{m}^{-2} \mathrm{~s}^{-1}$ on 18/6 (Light/Dark) cycle. Those were the optimum growth conditions. Growth was also tested over other temperatures and light intensities and was found to completely cease at $40{ }^{\circ} \mathrm{C}$ and high light intensity greater than $60 \mu$ mol photon $\mathrm{m}^{-2}$ $\mathrm{s}^{-1}$. On the other hand, Calothrix sp. was optimally grown at $30{ }^{\circ} \mathrm{C}$ and low light intensity of $15 \mu \mathrm{mol}$ photon $\mathrm{m}^{-2} \mathrm{~s}^{-1}$. The growth of Calothrix sp. completely ceased at high light intensity greater than $80 \mu \mathrm{mol}$ photon $\mathrm{m}^{-2} \mathrm{~s}^{-1}$. Cultures were placed under white light supplied by fluorescent tubes and under green and red light obtained by monochromatic green and red special filters. Three replicates of each treatment were grown as batch cultures of $100 \mathrm{ml}$ volume with no agitation and the measurements of growth-related metabolites and pigments were taken after one month of inoculation.

The growth medium used was BG-11 with its components supplied in standard concentrations (Rippka et al., 1979) except for the nutrient modifications according to the type of nutrient tested as follows: Quarter the standard concentration of the key nutrient tested (iron, nitrogen or phosphorus) 
BG-11 medium and half the standard concentration in original BG-11 medium. Those treatments will be occasionally referred to as nutrient limitation conditions In addition to those stressful treatments, two other treatments were employed namely standard concentration of key nutrients and double the standard concentration of the key nutrient tested in original BG-11. The latter treatment represents a nutrient-replete condition.

\section{Measurements of growth-related metabolites.}

\section{Peptide-N}

The procedure of Lowry et al. (1951) was followed for measurements of peptide-N. A sample of the ethanolic extract (75\%) was mixed with $1 \mathrm{ml}$. freshly mixed in $(1: 1 \mathrm{v} / \mathrm{v})$ solution of $2 \%$ sodium carbonate in $4 \%$ sodium hydroxide and $0.5 \%$ copper sulphate in $1 \%$ sodium tartarate. The mixture stood 10 minutes before addition of 0.1 Folin's reagent and made up to a definite volume. The optical density of the mixture was measured, after 30 minutes, at $700 \mathrm{~nm}$ using Cecil Spectrophotometer 2501 at the Algal and Physiology laboratory, Faculty of Science, Helwan University, Egypt.

\section{Total sugars}

Total sugars were determined by using the anthrone technique as described by Umbriet $\boldsymbol{e t}$ al. (1959). $6 \mathrm{ml}$ anthrone solution $\left(2 \mathrm{~g} \cdot \mathrm{l}^{-1} \mathrm{H}_{2} \mathrm{SO}_{4}\right)$ were added to $3 \mathrm{ml}$ sample and maintained on a boiling water bath for $3 \mathrm{~min}$. After cooling, the developed colour was measured spectrophotometerically at $620 \mathrm{~nm}$ using Cecil spectrophotometer 1000, at the Algal and Physiology laboratory, Faculty of Science, Helwan University, Egypt.

\section{Measurements of pigments}

\section{Cholorphyll $a$ and total carotenoids}

Chlorophyll $a$ is the only chlorophyll found in cyanobacteria. The chlorophyll- $a$ and total carotenoids contents were determined in $80 \%(\mathrm{v} / \mathrm{v})$ acetone extracts of cells incubated for $30 \mathrm{~min}$ at $30^{\circ} \mathrm{C}$ and then for $16 \mathrm{~h}$ at $4{ }^{\circ} \mathrm{C}$. Chlorophyll $a$ and total carotenoids concentrations were calculated according to McKinney (1941) in the supernatants after the acetone extracts were centrifuged at $15000 \mathrm{rpm}$ for $10 \mathrm{~min}$. The absorbance was measured spectrophotometerically at 663 and $460 \mathrm{~nm}$, respectively, using Cecil Spectrophotometer 1000, at the Algal and Physiology laboratory, Faculty of Science, Helwan University, Egypt.

\section{Phycobiliproteins}

The three phycobiliproteins: phycocyanin, phycoerythrin and allophycocyanin were measured according to Bennet and Bogard (1973). Cultures were sonicated for 40 seconds to break up cells and release the watersoluble phycobiliprotein pigments. This is followed by centrifugation at $8000 \mathrm{rpm}$ 
to remove cell debris. Phycobiliproteins concentration was calculated according to the following equations in $\mu \mathrm{g} . \mathrm{ml}^{-1}$.

$[$ Phycocyanin $]=1000 \cdot\left[\mathrm{OD}_{615}-0.474\left(\mathrm{OD}_{652}\right) / 5.34\right]$

[Allophycocyanin] $=1000 .\left[\mathrm{OD}_{652}-0.208\left(\mathrm{OD}_{615}\right) / 5.09\right]$

$[$ Phycoerythrin $]=1000 .\left[\mathrm{OD}_{562}-2.41(\mathrm{PC})-0.849(\mathrm{APC}) / 9.62\right]$

The optical density (absorbance) was measured spectrophotometerically using Cecil Spectrophotometer 1000, at the Algal and Physiology laboratory, Faculty of Science, Helwan University, Egypt.

\section{Statistical analysis}

Statistical analysis was performed using the MINITAB statistical software package (release 13.32, MINITAB Inc., USA). The multivariate analysis was performed using statistical function of Analysis of Variance (ANOVA), General Linear Model. The probability value (P value) signifies the acceptance of null hypothesis, i.e. results obtained by random chance) only if $\mathrm{P}$ value was more than 0.05 , hence indicating non-significant effect of factor tested. On the other hand, $\mathrm{P}$ value would signify the rejection of the null hypothesis if $\mathrm{P}$ value is less than 0.05 , thus indicating low probability of obtaining the results by random chance and confirming the significant effect of the factor tested.

The main factors tested were mainly: the element type (iron, phosphorus or nitrogen), the concentration of nutrients (standard, half, quarter and double the original concentration of each nutrient tested), generic difference (A. flos-aquae or Calothrix sp.) and light quality (white, red and blue in case of phycobiliproteins) in addition to their interaction effects, i.e. combined effects.

\section{Results}

Phosphorus limitation, demonstrated in half and quarter the concentration of medium phosphorus, caused the highest reduction in both peptide nitrogen and total sugars in A. flos-aquae but only lowest peptide nitrogen in Calothrix sp. Decreasing the concentration of iron caused a considerable reduction in both peptide nitrogen and total sugars for both isolates. Nitrogen availability caused fluctuations in peptide nitrogen in Calothrix sp. but this parameter increased with nitrogen decrease. Under double concentration of the nutrients tested, both peptide nitrogen and total sugars increased for both isolates. The effects of element type, concentration of nutrients and generic differences on growth-related metabolites were statistically evaluated. As an indicator of protein level, peptide-nitrogen showed a considerable variation for both isolates. For A. flos-aquae, nutrients concentration was highly effective in inducing significant changes in peptide nitrogen (ANOVA, $\mathrm{p}<0.001, \mathrm{n}=30$ ), on contrary to effect of element type which was non-significant (ANOVA, $\mathrm{p}=0.654, \mathrm{n}=30$ ). For Calothrix sp., element type was not effective in inducing significant changes in the peptide nitrogen 
(ANOVA, $\mathrm{p}=0.187, \mathrm{n}=30$ ) whereas the concentration of nutrients was highly effective in inducing significant changes (ANOVA, $\mathrm{p}=0.004, \mathrm{n}=30$ ). Generally, peptide nitrogen decreased as nutrients decreased but was less affected by nitrogen limitation in A. flos-aquae than in Calothrix sp. (Table 1). Regarding total sugars, they were neither affected by element type nor by the nutrient concentration (ANOVA, $\mathrm{p}=0.829$ and $\mathrm{p}=0.76$, respectively, $\mathrm{n}=30$ for each analysis) for A. flos-aquae. For Calothrix sp., nutrients concentration was relatively effective in inducing changes in total sugars (ANOVA, $\mathrm{p}=0.041, \mathrm{n}=30$ ) on contrary to the effect of the element tested which was non significant (ANOVA, $\mathrm{p}=0.224, \mathrm{n}=30$ ) (Table 1$)$.

Table (1): The effect of different nutrients' treatments on content of total sugars and peptide nitrogen of Anabaena flos-aquae and Calothrix sp. PCC7601.

\begin{tabular}{|c|c|c|c|c|}
\hline Treatments & $\begin{array}{c}\text { Total sugars } \\
\text { of } A . \text { flos- }^{-} \\
\text {aquae } \\
\left(\mathrm{mg} \cdot \mathrm{ml}^{-1}\right)\end{array}$ & $\begin{array}{l}\text { Peptide-N of } \\
\text { A. flos-aquae } \\
\quad\left(\mathrm{mg} \cdot \mathrm{ml}^{-1}\right)\end{array}$ & $\begin{array}{l}\text { Total sugars of } \\
\text { Calothrix sp. } \\
\left(\mathrm{mg} . \mathrm{ml}^{-1}\right)\end{array}$ & $\begin{array}{l}\text { Peptide-N of } \\
\text { Calothrix sp. } \\
\quad\left(\mathrm{mg} \cdot \mathrm{ml}^{-1}\right)\end{array}$ \\
\hline $\begin{array}{l}\text { Standard nutrient } \\
\text { concentration }\end{array}$ & $27.50 \pm 1.06$ & $16.30 \pm 2.42$ & $44.23 \pm 6.00$ & $18.05 \pm 3.60$ \\
\hline Quarter conc. of iron & $34.10 \pm 3.10$ & $12.68 \pm 1.68$ & $25.70 \pm 2.06$ & $15.58 \pm 1.40$ \\
\hline Half conc. of iron & $27.20 \pm 3.43$ & $12.83 \pm 1.64$ & $33.88 \pm 4.02$ & $17.03 \pm 2.22$ \\
\hline Double conc. of iron & $21.40 \pm 1.40$ & $22.50 \pm 4.88$ & $47.88 \pm 4.86$ & $29.48 \pm 4.02$ \\
\hline Quarter conc. of phosphorus & $25.00 \pm 2.66$ & $10.29 \pm 1.84$ & $35.88 \pm 1.42$ & $14.14 \pm 2.06$ \\
\hline Half conc. of phosphorus & $26.90 \pm 2.00$ & $12.23 \pm 2.20$ & $38.23 \pm 2.46$ & $17.11 \pm 1.44$ \\
\hline Double conc. of phosphorus & $35.00 \pm 3.06$ & $27.20 \pm 3.52$ & $55.46 \pm 3.86$ & $21.70 \pm 1.00$ \\
\hline Quarter conc. of nitrogen & $35.00 \pm 4.08$ & $12.08 \pm 4.34$ & $38.47 \pm 2.10$ & $13.68 \pm 2.08$ \\
\hline Half conc. of nitrogen & $30.30 \pm 2.04$ & $13.20 \pm 2.26$ & $14.38 \pm 8.62$ & $45.32 \pm 4.02$ \\
\hline Double conc. of nitrogen & $26.30 \pm 3.46$ & $26.10 \pm 2.64$ & $45.92 \pm 1.04$ & $22.34 \pm 2.00$ \\
\hline
\end{tabular}

Regarding pigments, chlorophyll $a$ was relatively significantly affected by concentration of nutrients (ANOVA, $\mathrm{p}=0.016, \mathrm{n}=30$ ) in A. flos-aquae but was not significantly affected by element type (ANOVA, $\mathrm{p}=0.179, \mathrm{n}=30$ ). Similarly, the effect of element type on chlorophyll- $a$ content in Calothrix sp. was nonsignificant (ANOVA, $\mathrm{p}=0.966, \mathrm{n}=30$ ). Difference in the chlorophyll- $a$ due to generic difference between A. flos-aquae and Calothrix was highly significant (ANOVA, $\mathrm{p}<0.001, \mathrm{n}=30$ ) but the combined effects of generic difference with element type and nutrients concentration were all non-significant. Extreme iron limitation which is quarter the normal iron concentration in BG-11 showed lowest chlorophyll- $a$ content in both isolates.

Regarding carotenoids, they were not significantly affected by types of elements tested (ANOVA, $\mathrm{p}=0.516, \mathrm{n}=30$ ) nor by concentration of nutrients tested. (ANOVA, $\mathrm{p}=0.29, \mathrm{n}=30$ ) in A. flos-aquae. Similar results were obtained for Calothrix sp. where effect of element (type or tested) was non-significant 
(ANOVA, $\mathrm{p}=0.634, \mathrm{n}=30$ ) as well as effect of concentration (ANOVA, $\mathrm{p}=0.061$, $\mathrm{n}=30$ ). Difference in the carotenoids due to generic difference was non significant (ANOVA, $\mathrm{p}=0.696, \mathrm{n}=30$ ) as well as the combined effects of generic difference with element type and nutrients concentration which were all non-significant. Generally, increased carotenoids content was observed under half the concentration of all nutrients tested (Table 2).

Table (2:) The effect of different nutrient treatments on chlorophyll $a$ and carotenoids content.

\begin{tabular}{|c|c|c|c|c|}
\hline \multirow{2}{*}{ Treatments } & \multicolumn{2}{|c|}{$\begin{array}{c}\text { Total chlorophyll- } a \text { ( } \mu \text { g.ml } \\
\pm(\text { standard deviation) }\end{array}$} & \multicolumn{2}{|c|}{$\begin{array}{l}\text { Total carotene } \mu \mathrm{g} / \mathrm{ml}^{-1} \\
\pm(\text { standard deviation })\end{array}$} \\
\hline & A. flos-aquae & Calothrix sp. & A.flos aquae & Calothrix sp. \\
\hline Standard nutrient concentration & $10.19 \pm 1.10$ & $17.23 \pm 2.70$ & $092.73 \pm 3.14$ & $102.46 \pm 2.50$ \\
\hline Quarter conc. of iron & $05.84 \pm 1.12$ & $14.58 \pm 2.60$ & $088.06 \pm 4.45$ & $100.49 \pm 3.10$ \\
\hline Half conc. of iron & $09.89 \pm 1.95$ & $15.41 \pm 1.20$ & $099.46 \pm 9.44$ & $69.65 \pm 4.10$ \\
\hline Double conc. of iron & $14.76 \pm 2.42$ & $18.41 \pm 1.50$ & $090.49 \pm 5.95$ & $120.85 \pm 2.30$ \\
\hline Quarter conc. of phosphorus & $06.91 \pm 1.83$ & $14.84 \pm 1.90$ & $084.30 \pm 3.12$ & $100.50 \pm 5.30$ \\
\hline Half conc. of phosphorus & $09.62 \pm 0.32$ & $15.77 \pm 2.03$ & $105.54 \pm 1.53$ & $69.65 \pm 2.40$ \\
\hline Double conc. of phosphorus & $11.44 \pm 1.86$ & $17.23 \pm 2.08$ & $069.12 \pm 3.18$ & $90.94 \pm 3.20$ \\
\hline Quarter conc. of nitrogen & $09.48 \pm 1.14$ & $12.79 \pm 2.10$ & $095.91 \pm 9.68$ & $55.11 \pm 2.40$ \\
\hline Half conc. of nitrogen & $10.45 \pm 1.32$ & $15.24 \pm 2.2$ & $095.29 \pm 3.10$ & $70.55 \pm 5.20$ \\
\hline Double conc. of nitrogen & $12.50 \pm 2.98$ & $20.69 \pm 1.40$ & $092.51 \pm 6.72$ & $109.22 \pm 3.70$ \\
\hline
\end{tabular}


Regarding total phycobiliproteins which is the sum of the accessory pigments content; phycocyanin, phycoerythrin and allophycocyanin, the effect of light quality and nutrients concentration on those pigments was prominent under low nutrient concentrations, i.e. quarter and half of the original concentration of BG-11 medium where they decreased (Table 3). The difference in phycobiliproteins content between treatments was highly significant. This was as judged from the small value of probability factor (p) thus rejecting the null hypothesis that these results were obtained by random chance and accepting the significant influence of the factor tested. Those significant results were mainly due to light quality employed (ANOVA, $\mathrm{p}<0.001, \mathrm{n}=60$ ), concentration of nutrients (ANOVA, $\mathrm{p}=0.001, \mathrm{n}=60$ ) but was least significant due to element type (ANOVA, $\mathrm{p}=0.053, \mathrm{n}=60$ ). The effect of those treatments on individual pigments was statistically evaluated.

Table (3): The effect of different light qualities on total phycobiliproteins content. Numbers are rounded up to the closest integer.

\begin{tabular}{|c|c|c|c|c|c|c|}
\hline \multirow[t]{2}{*}{ Treatments } & \multicolumn{2}{|c|}{$\begin{array}{c}\text { Total } \\
\text { phycobiliproteins } \\
\text { in white light } \\
\left(\mu \mathrm{g} . \mathrm{ml}^{-1}\right)\end{array}$} & \multicolumn{2}{|c|}{$\begin{array}{c}\text { Total } \\
\text { phycobiliproteins } \\
\text { in green light } \\
\left(\mu \mathrm{g} \cdot \mathrm{ml}^{-1)}\right.\end{array}$} & \multicolumn{2}{|c|}{$\begin{array}{c}\text { Total } \\
\text { phycobiliproteins } \\
\text { in red light } \\
\left(\mu \mathrm{g} . \mathrm{ml}^{-1}\right)\end{array}$} \\
\hline & $\begin{array}{l}\text { A. flos- } \\
\text { aquae }\end{array}$ & $\begin{array}{c}\text { Calothrix } \\
\text { sp. }\end{array}$ & $\begin{array}{c}\text { A. flos- } \\
\text { aquae }\end{array}$ & $\begin{array}{c}\text { Calothri } \\
x \text { sp. }\end{array}$ & $\begin{array}{c}\text { A. flos- } \\
\text { aquae }\end{array}$ & $\begin{array}{c}\text { Calothrix } \\
\text { sp. }\end{array}$ \\
\hline $\begin{array}{l}\text { Standard nutrient } \\
\text { concentration }\end{array}$ & 69 & 88 & 51 & 94 & 27 & 91 \\
\hline Quarter conc. of iron & 64 & 68 & 33 & 75 & 19 & 43 \\
\hline Half conc. of iron & 64 & 80 & 42 & 97 & 30 & 57 \\
\hline Double conc. of iron & 72 & 130 & 50 & 119 & 50 & 104 \\
\hline Quarter conc. of phosphorus & 14 & 56 & 8 & 99 & 13 & 92 \\
\hline Half conc. of phosphorus & 32 & 75 & 34 & 108 & 21 & 91 \\
\hline Double conc. of phosphorus & 74 & 94 & 66 & 126 & 28 & 101 \\
\hline Quarter conc. of nitrogen & 32 & 75 & 26 & 86 & 21 & 93 \\
\hline Half conc. of nitrogen & 57 & 76 & 38 & 106 & 25 & 95 \\
\hline Double conc. of nitrogen & 70 & 85 & 32 & 141 & 30 & 112 \\
\hline
\end{tabular}

Concerning phycocyanin, this pigment was highest in content and predominated other pigments at double concentrations of nitrogen in both cyanobacterial strains under red light. On contrary, there was a considerable decrease in this pigment under green light in both isolates. The pigment content decreased with the reduction of the three nutrients concentrations. Calothrix sp. possessed more phycocyanin pigment than A. flos-aquae under all treatments (Table 4). For A. flos-aquae, the effect of light quality was highly-significant (ANOVA, $\mathrm{p}<0.001, \mathrm{n}=90$ ); as well as the effect of concentration (ANOVA, $\mathrm{p}=$ $0.009, \mathrm{n}=90$ ). On contrary, the effect of element type on inducing changes in 
phycocyanin content was highly significant (ANOVA, $\mathrm{p}=0.05, \mathrm{n}=90$ ). The combined effect for element type and light quality (ANOVA, $\mathrm{p}=0.479, \mathrm{n}=90$ ), was non significant as well as the combined effect of element type and nutrients concentration (ANOVA, $\mathrm{p}=0.566, \mathrm{n}=90$ ). Nevertheless, the combined effect of light quality and nutrients concentration was non-significant (ANOVA, $p=0.108$, $\mathrm{n}=90$ ). For Calothrix sp., the effect of element was non-significant (ANOVA, $\mathrm{p}=$ $0.559, \mathrm{n}=90$ ); on contrary to the effect of light quality (ANOVA, $\mathrm{p}<0.001, \mathrm{n}=30$ ) and nutrients concentration (ANOVA, $\mathrm{p}<0.001, \mathrm{n}=90$ ) which were highly significant in inducing changes in this pigment.

Table (4): the effect of different light qualities and nutrients concentration on individual phycocyanin pigment.

\begin{tabular}{|c|c|c|c|c|c|c|}
\hline \multirow[t]{2}{*}{ Treatments } & \multicolumn{2}{|c|}{$\begin{array}{l}\text { Phycocyanin } \\
\text { in white light } \\
\left(\mu \mathrm{g} . \mathrm{ml}^{-1}\right) \pm \mathrm{SD}\end{array}$} & \multicolumn{2}{|c|}{$\begin{array}{c}\text { Phycocyanin } \\
\text { in green light } \\
\left(\mu \mathrm{g} . \mathrm{ml}^{-1}\right) \pm \mathrm{SD}\end{array}$} & \multicolumn{2}{|c|}{$\begin{array}{c}\text { Phycocyanin } \\
\text { in red light } \\
\left(\mu \mathrm{g} . \mathrm{ml}^{-1}\right) \pm \mathrm{SD}\end{array}$} \\
\hline & $\begin{array}{l}\text { A. flos- } \\
\text { aquae }\end{array}$ & $\begin{array}{c}\text { Calothrix } \\
\text { sp. }\end{array}$ & $\begin{array}{l}\text { A. flos- } \\
\text { aquae }\end{array}$ & $\begin{array}{c}\text { Calothrix } \\
\text { sp. }\end{array}$ & $\begin{array}{l}\text { A. flos- } \\
\text { aquae }\end{array}$ & $\begin{array}{c}\text { Calothrix } \\
\text { sp. }\end{array}$ \\
\hline $\begin{array}{l}\text { Standard nutrient } \\
\text { concentration }\end{array}$ & $23.60 \pm 4.2$ & $18.83 \pm 3.2$ & $8.85 \pm 2.8$ & $9.42 \pm 1.3$ & $7.27 \pm 1.4$ & $45.65 \pm 5.9$ \\
\hline $\begin{array}{l}\text { Quarter conc. of } \\
\text { iron }\end{array}$ & $21.97 \pm 1.9$ & $13.29 \pm 1.3$ & $6.05 \pm 1.1$ & $4.11 \pm 1.0$ & $7.15 \pm 1.2$ & $13.74 \pm 1.1$ \\
\hline Half conc. of iron & $24.87 \pm 2.7$ & $18.14 \pm 1.6$ & $3.81 \pm 0.8$ & $9.08 \pm 1.5$ & $\begin{array}{c}17.85 \pm \\
1.8\end{array}$ & $23.34 \pm 2.3$ \\
\hline $\begin{array}{l}\text { Double conc. of } \\
\text { iron }\end{array}$ & $27.30 \pm 2.0$ & $40.01 \pm 2.1$ & $4.95 \pm 0.9$ & $10.96 \pm 1.4$ & $24.8 \pm 2.6$ & $48.61 \pm 4.1$ \\
\hline $\begin{array}{l}\text { Quarter conc. of } \\
\text { phosphorus }\end{array}$ & $2.20 \pm 0.6$ & $12.83 \pm 1.2$ & $2.27 \pm 0.4$ & $0.83 \pm 0.2$ & $5.7 \pm 0.3$ & $40.43 \pm 3.2$ \\
\hline $\begin{array}{l}\text { Half conc. of } \\
\text { phosphorus }\end{array}$ & $11.70 \pm 1.6$ & $13.56 \pm 2.0$ & $7.20 \pm 4.1$ & $6.46 \pm 0.9$ & $5.78 \pm 0.7$ & $43.01 \pm 3.1$ \\
\hline $\begin{array}{l}\text { Double conc. of } \\
\text { phosphorus }\end{array}$ & $29.08 \pm 3.1$ & $20.32 \pm 1.1$ & $4.78 \pm 1.9$ & $14.32 \pm 1.3$ & $14.2 \pm 1.7$ & $52.67 \pm 2.1$ \\
\hline $\begin{array}{l}\text { Quarter conc. of } \\
\text { nitrogen }\end{array}$ & $14.33 \pm 1.5$ & $15.19 \pm 1.9$ & $3.40 \pm 0.8$ & $3.88 \pm 0.9$ & $13.6 \pm 1.8$ & $36.26 \pm 2.5$ \\
\hline $\begin{array}{l}\text { Half conc. of } \\
\text { nitrogen }\end{array}$ & $22.14 \pm 1.7$ & $17.22 \pm 1.6$ & $5.83 \pm 0.9$ & $6.28 \pm 1.3$ & $15.6 \pm 1.5$ & $40.91 \pm 2.9$ \\
\hline $\begin{array}{l}\text { Double conc. of } \\
\text { nitrogen }\end{array}$ & $23.13 \pm 2.2$ & $19.00 \pm 1.4$ & $9.15 \pm 1.3$ & $10.05 \pm 1.5$ & $16.5 \pm 1.9$ & $56.55 \pm 2.3$ \\
\hline
\end{tabular}

The combined effect for element and light (ANOVA, $p=0.021, n=90$ ), was relatively significant unlike the combined effect of element and concentration (ANOVA, $\mathrm{p}=0.472, \mathrm{n}=90$ ) and the combined effect of light and concentration was highly significant (ANOVA, $\mathrm{p}=0.318, \mathrm{n}=90$ ). Difference in this pigment due to generic difference was highly significant (ANOVA, $\mathrm{p}<<0.0001, \mathrm{n}=180$ ) as well as the combined effect between genera and light (ANOVA, p $<<0.0001$, 
$\mathrm{n}=180$ ) but the combined effects of generic difference with element, concentration or light were all non-significant.

Concerning allophycocyanin, it showed an increase at all double concentration of all nutrients tested but decreased under half and quarter concentrations of the nutrients tested under different light treatments (white, red and green light) for both isolates (Table 5).

Table (5): the effect of different light qualities and nutrients concentrations on allophycocyanin pigment.

\begin{tabular}{|c|c|c|c|c|c|c|}
\hline \multirow[t]{2}{*}{ Treatments } & \multicolumn{2}{|c|}{$\begin{array}{c}\text { Allophycocyanin } \\
\text { in white light } \\
\left(\mu \mathrm{g} \cdot \mathrm{ml}^{-1}\right) \pm \mathrm{SD}\end{array}$} & \multicolumn{2}{|c|}{$\begin{array}{l}\text { Allophycocyanin } \\
\text { in green light } \\
\left(\mu \mathrm{g} . \mathrm{ml}^{-1}\right) \pm \mathrm{SD}\end{array}$} & \multicolumn{2}{|c|}{$\begin{array}{l}\text { Allophycocyanin } \\
\text { in red light } \\
\left(\mu \mathrm{g} . \mathrm{ml}^{-1}\right) \pm \mathrm{SD}\end{array}$} \\
\hline & $\begin{array}{l}\text { A. flos- } \\
\text { aquae }\end{array}$ & $\begin{array}{l}\text { Calothrix } \\
\text { sp. }\end{array}$ & $\begin{array}{l}\text { A. flos- } \\
\text { aquae }\end{array}$ & $\begin{array}{l}\text { Calothrix } \\
\text { sp. }\end{array}$ & $\begin{array}{l}\text { A. flos- } \\
\text { aquae }\end{array}$ & $\begin{array}{c}\text { Calothrix } \\
\text { sp. }\end{array}$ \\
\hline $\begin{array}{l}\text { Standard } \\
\text { nutrient } \\
\text { concentration }\end{array}$ & $21.81 \pm 2.2$ & $28.06 \pm 2.0$ & $18.0 \pm 1.4$ & $27.80 \pm 2.9$ & $11.22 \pm 1.5$ & $45.65 \pm 3.1$ \\
\hline $\begin{array}{l}\text { Quarter conc. of } \\
\text { iron }\end{array}$ & $19.11 \pm 1.8$ & $23.43 \pm 1.6$ & $10.03 \pm 1.1$ & $19.38 \pm 2.1$ & $5.43 \pm 0.8$ & $25.57 \pm 2.6$ \\
\hline $\begin{array}{l}\text { Half conc. of } \\
\text { iron }\end{array}$ & $21.60 \pm 1.4$ & $27.58 \pm 1.5$ & $16.17 \pm 1.2$ & $33.16 \pm 4.1$ & $8.73 \pm 1.2$ & $27.19 \pm 2.3$ \\
\hline $\begin{array}{l}\text { Double conc. of } \\
\text { iron }\end{array}$ & $24.91 \pm 2.6$ & $40.89 \pm 1.2$ & $18.98 \pm 2.1$ & $37.73 \pm 6.0$ & $20.10 \pm 2.1$ & $47.05 \pm 4.3$ \\
\hline $\begin{array}{l}\text { Quarter conc. of } \\
\text { phosphorus }\end{array}$ & $5.33 \pm 1.1$ & $19.93 \pm 1.6$ & $2.61 \pm 0.9$ & $43.95 \pm 4.7$ & $4.61 \pm 0.8$ & $48.80 \pm 4.2$ \\
\hline $\begin{array}{l}\text { Half conc. of } \\
\text { phosphorus }\end{array}$ & $10.37 \pm 2.0$ & $26.91 \pm 3.0$ & $16.23 \pm 2.1$ & $45.16 \pm 2.9$ & $8.32 \pm 0.9$ & $45.10 \pm 4.9$ \\
\hline $\begin{array}{l}\text { Double conc. of } \\
\text { phosphorus }\end{array}$ & $26.14 \pm 2.1$ & $32.87 \pm 3.1$ & $20.0 \pm 1.0$ & $44.70 \pm 3.6$ & $9.13 \pm 2.1$ & $44.85 \pm 4.8$ \\
\hline $\begin{array}{l}\text { Quarter conc. of } \\
\text { nitrogen }\end{array}$ & $8.53 \pm 2.2$ & $25.35 \pm 2.9$ & $5.29 \pm 0.7$ & $32.82 \pm 2.1$ & $4.22 \pm 0.9$ & $54.99 \pm 5.4$ \\
\hline $\begin{array}{l}\text { Half conc. of } \\
\text { nitrogen }\end{array}$ & $12.88 \pm 2.1$ & $27.08 \pm 3.1$ & $10.17 \pm 1.1$ & $49.87 \pm 4.4$ & $3.70 \pm 0.6$ & $52.58 \pm 4.8$ \\
\hline $\begin{array}{l}\text { Double conc. of } \\
\text { nitrogen }\end{array}$ & $22.78 \pm 4.1$ & $29.68 \pm 3.4$ & $9.88 \pm 1.3$ & $52.89 \pm 4.9$ & $4.02 \pm 0.9$ & $52.06 \pm 4.9$ \\
\hline
\end{tabular}

The effect of light quality was highly significant (ANOVA, $\mathrm{p}<0.001$, $\mathrm{n}=$ 90); as well as the effect of nutrients concentration (ANOVA, $\mathrm{p}=0.001, \mathrm{n}=90$ ) in A. flos-aquae. However, the effect of element type on inducing changes in allophycocyanin content was relatively significant (ANOVA, $\mathrm{p}=0.023, \mathrm{n}=90$ ). The combined effect for element type and light quality (ANOVA, $\mathrm{p}=0.707$, $\mathrm{n}=90$ ), was non significant as well as the combined effect of element type and nutrients concentration (ANOVA, $\mathrm{p}=0.515, \mathrm{n}=90$ ). Nevertheless, the combined effect of light quality and nutrients concentration was non-significant (ANOVA, $p$ $=0.488, \mathrm{n}=90$ ).

For Calothrix sp., the effect of element type was relatively-significant (ANOVA, $\mathrm{p}=0.032, \mathrm{n}=90$ ); on contrary to the effect of light quality (ANOVA, $\mathrm{p}$ $<0.001, \mathrm{n}=30$ ) and nutrients concentration (ANOVA, $\mathrm{p}=0.018, \mathrm{n}=90$ ) which Egyptian J. of Phycol. Vol. 10, 2009 -48 - 
were significant in inducing changes in this pigment. The combined effect of light quality and element type and light quality and nutrients concentration and element type and nutrients concentration were all non-significant (ANOVA, $\mathrm{p}=0.101, \mathrm{p}=$ $0.721, \mathrm{p}=0.055$, respectively, $\mathrm{n}=90$ for each analysis). Difference in this pigment due to generic difference was highly significant (ANOVA, $\mathrm{p}<0.001, \mathrm{n}=180$ ). The combined effect for generic difference and element type (ANOVA, $p=0.004$, $\mathrm{n}=180$ ), was highly significant as well as the combined effect of generic difference and light quality (ANOVA, $\mathrm{P}<0.001, \mathrm{n}=180$ ) and the combined effect of generic difference and nutrients concentration was non significant (ANOVA, $p$ $=0.438, \mathrm{n}=180$ ).

Concerning phycoerythrin, the pigment content was observed to predominate other pigments at all reduced concentrations of nutrients, i.e., half and quarter concentration of phosphorus and iron tested, under white light in Calothrix sp. Whereas in A. flos-aquae, the levels of phycoerythrin were comparable to the levels other phycobiliprotein pigments under white light. The highest content was recorded under green light in Calothrix sp. and A. flos aquae under different nutrients treatments. Phycoerythrin pre-dominated the other phycobiliprotein pigments under green light at quarter and half nutrients concentration. Nevertheless, the phycoerythrin content was considerably reduced under red light in both isolates (Table 6). Statistically, the effect of light quality was highly-significant (ANOVA, $\mathrm{p}=0.001, \mathrm{n}=90$ ); whereas the effect of concentration (ANOVA, $\mathrm{p}=0.043, \mathrm{n}=90$ ) was slightly significant in A. flosaquae. However, the effect of element on inducing changes in phycoerythrin content was non-significant (ANOVA, $\mathrm{p}=0.51, \mathrm{n}=90$ ). The combined effect for element type and light quality (ANOVA, $\mathrm{p}=0.542, \mathrm{n}=90$ ), was non significant as well as the combined effect of element and concentration (ANOVA, $p=0.825$, $\mathrm{n}=90$ ) and the combined effect of light and concentration (ANOVA, $\mathrm{p}=0.361$, $\mathrm{n}=90$ ). For Calothrix sp., the effect of element type was relatively-significant (ANOVA, $\mathrm{p}=0.016, \mathrm{n}=90$ ); on contrary to the effect of light (ANOVA, $\mathrm{p}<$ $0.001, \mathrm{n}=90$ ) and nutrients concentration (ANOVA, $\mathrm{p}<0.001, \mathrm{n}=90$ ) which were significant in inducing changes in this pigment. The combined effect of light quality and element type and element type and nutrients concentration were all non-significant (ANOVA, $\mathrm{p}=0.094, \mathrm{p}=0.565$, respectively, $\mathrm{n}=90$ each). On contrary, light and concentration combined effect induced significant changes (ANOVA, $\mathrm{p}=0.002, \mathrm{n}=90$ ). Differences between treatments in this pigment content due to generic difference was highly significant (ANOVA, $\mathrm{p}<0.001$, $\mathrm{n}=180$ ). The combined effect for generic difference and element type (ANOVA, $\mathrm{p}=0.834, \mathrm{n}=180$ ), was non significant as well as the combined effect of generic difference and nutrients concentration was non significant (ANOVA, $p=0.215$, 
$\mathrm{n}=180$ ). The combined effect of generic difference and light quality was highly significant (ANOVA, $\mathrm{p}<0.001, \mathrm{n}=180$ ).

Table (6): the effect of different light qualities and nutrients concentration on phycoerythrin pigment.

\begin{tabular}{|c|c|c|c|c|c|c|}
\hline \multirow[t]{2}{*}{ Treatments } & \multicolumn{2}{|c|}{$\begin{array}{c}\text { Phycoerythrin } \\
\text { in white light } \\
\left(\mu \text { g.ml }{ }^{-1}\right)\end{array}$} & \multicolumn{2}{|c|}{$\begin{array}{c}\text { Phycoerythrin } \\
\text { in green light } \\
\left(\mu \mathrm{g} . \mathrm{ml}^{-1)}\right.\end{array}$} & \multicolumn{2}{|c|}{$\begin{array}{l}\text { Phycoerythrin } \\
\text { in red light } \\
\left(\mu \mathrm{g} . \mathrm{ml}^{-1}\right)\end{array}$} \\
\hline & $\begin{array}{l}\text { A. flos- } \\
\text { aquae }\end{array}$ & $\begin{array}{c}\text { Calothrix } \\
\text { sp. }\end{array}$ & $\begin{array}{l}\text { A. flos- } \\
\text { aquae }\end{array}$ & $\begin{array}{l}\text { Calothrix } \\
\text { sp. }\end{array}$ & $\begin{array}{l}\text { A. flos- } \\
\text { aquae }\end{array}$ & $\begin{array}{c}\text { Calothrix } \\
\text { sp. }\end{array}$ \\
\hline $\begin{array}{l}\text { Standard } \\
\text { nutrient } \\
\text { concentration }\end{array}$ & $23.16 \pm 2.1$ & $40.70 \pm 2.1$ & $24.33 \pm 3.1$ & $57.12 \pm 5.1$ & $8.85 \pm 1.1$ & $7.42 \pm 1.4$ \\
\hline $\begin{array}{l}\text { Quarter conc. of } \\
\text { iron }\end{array}$ & $22.68 \pm 2.1$ & $31.32 \pm 4.1$ & $17.03 \pm 1.2$ & $51.27 \pm 4.7$ & $6.05 \pm 1.0$ & $3.75 \pm 0.5$ \\
\hline $\begin{array}{l}\text { Half conc. of } \\
\text { iron }\end{array}$ & $17.3 \pm 1.4$ & $33.71 \pm 3.3$ & $22.47 \pm 2.2$ & $54.60 \pm 5.8$ & $3.82 \pm 0.5$ & $6.38 \pm 1.2$ \\
\hline $\begin{array}{l}\text { Double conc. of } \\
\text { iron }\end{array}$ & $19.60 \pm 1.3$ & $48.99 \pm 4.9$ & $26.37 \pm 2.1$ & $70.66 \pm 7.1$ & $4.95 \pm 1.4$ & $8.07 \pm 2.1$ \\
\hline $\begin{array}{l}\text { Quarter conc. of } \\
\text { phosphorus }\end{array}$ & $6.61 \pm 1.3$ & $22.85 \pm 2.3$ & $3.0 \pm 0.9$ & $54.29 \pm 6.1$ & $2.27 \pm 0.8$ & $2.27 \pm 0.8$ \\
\hline $\begin{array}{l}\text { Half conc. of } \\
\text { phosphorus }\end{array}$ & $10.43 \pm 1.7$ & $34.27 \pm 4.1$ & $11.02 \pm 1.9$ & $56.43 \pm 5.8$ & $7.20 \pm 1.2$ & $2.52 \pm 0.9$ \\
\hline $\begin{array}{l}\text { Double conc. of } \\
\text { phosphorus }\end{array}$ & $18.97 \pm 3.0$ & $40.69 \pm 2.1$ & $41.40 \pm 4.7$ & $66.91 \pm 4.1$ & $4.78 \pm 1.3$ & $3.24 \pm 0.8$ \\
\hline $\begin{array}{l}\text { Quarter conc. of } \\
\text { nitrogen }\end{array}$ & $8.77 \pm 1.5$ & $34.12 \pm 1.0$ & $16.98 \pm 1.1$ & $49.33 \pm 3.7$ & $3.40 \pm 0.4$ & $1.52 \pm 0.1$ \\
\hline $\begin{array}{l}\text { Half conc. of } \\
\text { nitrogen }\end{array}$ & $21.83 \pm 2.1$ & $31.76 \pm 3.7$ & $21.87 \pm 1.6$ & $49.99 \pm 4.9$ & $5.83 \pm 1.3$ & $1.78 \pm 0.6$ \\
\hline $\begin{array}{l}\text { Double conc. of } \\
\text { nitrogen }\end{array}$ & $23.69 \pm 1.9$ & $36.60 \pm 4.4$ & $13.27 \pm 0.7$ & $77.65 \pm 6.1$ & $9.15 \pm 1.2$ & $3.33 \pm 0.5$ \\
\hline
\end{tabular}

XXXXXX

\section{Discussion}

Under white light, the growth-related metabolites were more affected by nutrients concentration rather than element type. This only emphasises that all of these nutrients are key elements in the growth medium of the two cyanobacterial strains. Proteins and chlorophyll- $a$ pigments are directly correlated with growth and photosynthetic activities of cyanobacteria. Limited growth is reflected in the decrease of cellular content of chlorophyll- $a$ and protein (Kaebernick $\boldsymbol{e t}$ al., 2000). This is due to the fact that stress condition can cause alternations in photosynthesis and the associated pigments and proteins (Grossman $\boldsymbol{e t}$ al., 2001). Total sugars, on the other hand are associated with photosynthetic activity (Fay, 1983) but can be also involved in stress tolerance under specific nutrients deficiency in some cyanobacteria (Allen and Hutchinson, 1984). This would explain its increase under some stressful nutrient treatments. However, some responses are characteristic of the deficiency of one particular nutrient, 
while others are general responses for deficiency of different nutrients. An example of those general responses is growth arrest and incompletion of cell division accompanied by change and degradation of sub-cellular structures (Singh and Sherman, 2002). The effect of iron and phosphorus availability seems to be more effective in inducing differences in growth-related metabolites than nitrogen. A. flos-aquae is a filamentous heterocystous cyanobacterium, hence a nitrogen fixer. In the presence of high available nitrogen in the medium, nitrogen fixation is not needed whereas in the absence of available nitrogen, heterocyst formation is enhanced and nitrogen fixation is induced (Haselkorn et al., 1989). Despite the fact that A. flos-aquae can compensate for the limited nitrogen supply in the medium through nitrogen fixation, there was a slight decline in peptide nitrogen. Heterocysts formation is usually accompanied by several biochemical changes including the degradation of nitrogenous cyanophycin granules and degradation of proteinaceous phycobilin pigments (Fay, 1983). The transforming heterocyst shows high proteolytic activity, and as a result of protease action about half of the proteins originally present in the undifferentiated cell are degraded during heterocyst development (Fay, 1983).

When cyanobacteria are starved for an essential nutrient, they turn yellow, in a process called "chlorosis" (Allen and Smith, 1969). It starts with the degradation of photosynthetic pigments, in particular, the phycobiliprotiens, as well as chlorophyll $a$, the main light harvesting pigment of photo-system I and II. The kinetics of pigment degradation is rather variable and depends on the specific nutrient that is absent as well as on other environmental conditions such as temperature and light (Barker-Astrom et al., 2005).

The general decline of chlorophyll under all nutrients limitation levels was observed. This is on contrary to the increase in chlorophyll $a$ content recorded for double the concentration of key nutrients tested. The lowest chlorophyll $a$ level was recorded under quarter the iron concentration condition which indicates that iron-limitation was most influential on chlorophyll $a$ content. Nevertheless, maximum chlorophyll $a$ content was recorded under double concentration of iron. Deficiency of $\mathrm{Fe}$ and $\mathrm{Mn}$ are known to inhibit chlorophyll $a$ synthesis (Popovic et al., 1977). Under nitrogen deficient conditions, much of the chlorophyll and phycobiliproteins associated with photosystem II units in vegetative cells are lost during differentiation (Fay, 1983). For carotenoids, extreme iron limitation did not stimulate excessive cartenogenesis which is similar to what Borowitzka $\boldsymbol{e t}$ al. (1991) reported. Similarly, Darwish (2005) found that total chlorophyll proportionally increased with the increase in iron concentration. The carotenoids on the other hand accumulated under starvation conditions but prolonged extreme starvation did not cause further carotenoid accumulation. This can be explained that different carotenoids molecules (e.g. $\beta$-carotene, lutein or astaxanthin) 
produced in the carotenoid pathway are esterified with triacyglycerol and sequestered into cytosolic lipid bodies under stress and aging conditions. The peripheral distributions of carotenoid-rich lipid bodies serve as a 'sunscreen' to prevent or reduce excess photooxidation under stress.

Triacylglycerol synthesis may also utilize phycocyanin, phycoerythrin and galactolipids or toxic fatty acids excluded from the membrane system as acyl donors, thereby detoxifying membrane lipids and depositing as triacylglycerol (Qiang Hu et al., 2008). Synthesis of triacyl glycerol and deposition of triacylglycerol into cytosolic lipid bodies may be, with few exceptions, the default pathway in algae under environmental stress conditions. (Qiang Hu et al., 2008). The relative increase in carotenoids under iron-replete condition is due to the fact that that iron is essential for carotenoid biosynthesis through iron-catalysed Fenton reaction (Kobayashi et al., 1993).

Modulation of the phycobilisome, the light-harvesting antenna typical of most cyanobacteria, upon nutrient depletion involves repression of synthesis of new pigments as well as active degradation of the existing ones. Cyanobacteria are generally thought to degrade phycocyanin as a source of endogenous nitrogen (Boussiba and Richmond, 1980). This is due to the fact that these pigments are found in abundance and their degradation may provide a substantial amount of nitrogen to nitrogen-limited cells. Furthermore, degradation of the phycobilisome during nutrient-limited growth may prevent photodamage that would occur if the cells were to absorb light under conditions of metabolic arrest (Schwarz and Fochhmmer, 2005). Verstreate et al. (1977) reported the phycobilin degradation for A. flos-aquae grown in the absence of iron. Armstrong and Van Baalen (1979) attributed this to the production of iron-chelating siderophores during iron starvation. Siderophores are mainly nitrogenous compounds and therefore their synthesis requires plenty of nitrogen mostly made available from phycobiliproteins degradation (Emery, 1971). Starvation for phosphorus (Collier and Grossman, 1992) or iron (Singh and Sherman, 2000) can result in substantial loss of pigment. Nitrogen starvation, on the other hand, exhibit rapid and complete phycobilisome degradation loss in Synechococcus (Collier and Grossman, 1992). Looking at the nitrogen treatment, we find that heterocyst formation was accompanied by decline in phycobiliproteins. This biochemical and structural change is characteristicis of heterocyst formation where heterocysts contain chlorophyll $a$ and carotenoids pigments but essentially lack phycobiliproteins (Fay, 1983)

In comparison to control medium condition, the results showed the general increase of growth, chlorophyll, growth-related metabolites and phycobiliproteins pigments content under different nutrients-replete conditions whereas the opposite was observed under nutrient limitation. On contrary, carotenoids increased under half concentrations of nutrients tested condition but 
decreased at the prolonged extreme depletion level. The effect of nitrogen limitation on growth and pigments content was overly less severe on A. flos-aquae than on Calothrix sp. due to the ability of A. flos-aquae to compensate for limited supply of available nitrogen through nitrogen fixation.

Under white light and at all nutrients stress levels, phycoerythrin pigments predominated than other phycobiliproteins pigments. However, in case of cells grown under green, phycocyanin and allophycocyanin were more abundant than phycoerythrin. Phycoerythrin accumulated under green light at reduced concentrations of different nutrients especially iron and phosphorus whereas the accumulation decreased but not completely suppressed under red light at standard and double nutrients concentrations. Phycocyanin, on the other hand, was highest under double concentration of all nutrients tested and predominated pigments in treatments placed under red light. The best economic conditions for maximum phycoerythrin pigment production resulted from the use of half the standard concentration of all the nutrients under green light quality. Whereas, the best phycocyanin was attained at double the standard concentration of nitrogen under red light.

\section{Conclusion}

Taken all together, it is observed that peptide-nitrogen and chlorophyll $a$ tend to increase under high concentration of key nutrients indicating enhanced growth. However, different cyanobacterial phycobiliproteins sometimes follow different trends according to the growth conditions applied, mainly; nutrients concentrations and light quality. The differential production of different types of phycobiliproteins under different nutrients levels and light quality can be used for manipulating the production of those pigments on a large scale. However, the selection of isolates highly responsive to these conditions is a prerequisite for successful production of those pigments. In that regard, Calothrix sp. seems to be more promising source of phycobiliproteins than A. flos-aquae and can be exploited in the future for commercial production of cyanobacterial valuable pigments. The study shows that the production of these pigments as natural environment-friendly substitutes for synthetic expensive hazardous analogues is feasible once the correct growth conditions are secured.

\section{References}

Allen, M. M. and Smith, A. J. (1969). Nitrogen chlorosis in blue-green algae. Arch. Microbiol., 69:114-120.

Allen, M. M. and Hutchinson, F. (1980). Nitrogen limitation and recovery in the cyanobacterium Aphanocapsa 6308. Arch. Microbiol., 128:1-7. 
Armstrong, J. E. and Van Baalen, C. (1979). Iron transport in microalgae: the isolation and biological activity of a hydroxamate siderophore from the blue-green alga Agmenellum quadruplicatum. Journal of General Microbiology, 111: 253- 262.

Barker-Astrom, K.; Schelin, J.; Gustafsson, P.; Clarke, A. K. and Campbell, D. A. (2005). Chlorosis during nitrogen starvation is altered by carbon dioxide and temperature status and is mediated by the ClpP1 protease in Synechococcus elongatus. Archives of Microbiology, 183: 66-69.

Bei, H. ; Guang-Ce, W. ; Chen-Kui, Z. and Zhen-gang, L. (2002). The experimental research of R- phycoerythrin subunits on cancer treatment A new photosensitizer in PDT. Cancer Biotherapy and Radiopharmcy, 17:35-42.

Bennett, A. and Bogard, A. (1973). Complementary chromatic adaptation in a filamentous blue-green algae. The Journal of Cell Biology, 58: 419 - 435.

Borowitzka, M. A.; Huisman, J. M. and Osborn, A. (1991). Culture of the astaxanthin-producing green alga Haematococcus pluvialis. I. Effects of nutrients on growth and cell. Journal of Applied Phycology, 3:295-304.

Boussiba, S. and Richmond, A. E. (1980). C-phycocyanin as a storage protein in the blue-green alga Spirulina platensis. Archives of Microbiology, 125:143-147.

Collier, J. L. and Grossman, A. R. (1992). Chlorosis induced by nutrient deprivation in Synechococcus sp. strain PCC 7942: not all bleaching is the same. Journal of Bacteriology, 174: 4718-4726.

Darwish, M. A. (2005). Studies on pigments of some greem algae. Ph.D thesis, Department of Food Science and Technology, Faculty of Agriculture, AlAzhar University, Egypt.

Datz, G. and Dohler, G. (1981). Light dependent changes in the lipid and fatty acid composition of phycocyanin free photosynthetic lamellae of Synechococcus. Zeitschrift für Naturforschung, 36c: 856-862.

De Loura, I. De Canto.; Dubacq, J. P. and Thomas, J. C. (1987). The effects of nitrogen deficiency on pigments and lipids of cyanobacteria. Journal of Plant Physiology, 83: 838-843.

Dufosse, L.; Galaup, P.; Yaron, A. ; Arad,S.; Blanc, B.; Chidambaramurthy, K.; Ravishanker, G. (2005) Microorganisms and microalgae as source of pigments for use: a scientific oddity or an industrial reality? Trends in Food Science and Technology, 16:389-406.

Emery, T. (1971). Hydroxamic acids of natural origin. Advances in Enzymology, 35:135-155.

Eng-Wilmont, D.L. and Martin, D. F. (1977). Growth response of the marine blue-green alga, Gomphosphaeria aponina, to inorganic nutrients and significance to management. Microbios, 19: 167-179.

Egyptian J. of Phycol. Vol. 10, 2009 
Fay, P. (1983). The blue-greens. Studies in Biology/ Institute of Biology; no., 160, Camelot Press, Southhampton, UK.

Glazer, A. N. (1994). Phycobiliproteins - a family of valuable, widely used flurophores. Journal of Applied Phycology, 6:105-112.

Grossman, A. R.; Bhaya, D. and He, Q. (2001). Tracking the light environment by cyanobacteria and the dynamic nature of light harvesting. Journal of Biological Chemistry, 276: 11449-11452.

Hardie, L. P.; Balkwill, D. L. and Stevens, S. E. (1983). Effects of iron starvation on the physiology of the cyanobacterium Agmenellum quadruplicatum. Journal of Applied and Environmental Microbiology, 45: 999-1006.

Haselkorn, R.; Golden, J. W.; Lammers, P. J. and Mulligan, M. E. (1989). Developmental rearrangement of cyanobacterial nitrogen-fixation genes. Trends in Genetics, 2:255-259.

Hu, Q.; Sommerfeld, M.; Jarvis, E.; Ghirardi, M.; Posewitz, M.; Seibert, M.; and Darzins, A. (2008). Microalgal triacylglycerols as feedstocks for biofuel production: perspectives and advances.The Plant Journal, 54: 621-639.

Kaebernick, M.; Nielan, B. A.; Börner, T. and Dittmann, E. (2000). Light and transcriptional response of the microcystin biosynthesis gene cluster. Applied and Environmental Microbiology, 66: 3387-3392.

Kimura, M. (1995). Dyeing with phycocyanin. JP Patent, 166480, 27 June.

Kobayashi, M.; Kakizono, T. and Nagai, S. (1993). Enhanced carotenoid biosynthesis by oxidative stress in acetate-induced cyst ells of a green unicellular alga Haematococcus pulvialis. Applied and Environmental Microbiology, 59: 867-873.

Lowry, O. H.; Rosebrough ,N. J.; Farr, A. L. and Randall, B. J. (1951). Protein measurements with the folin phenol reagent. Journal of Biological Chemistry, 193:265-275.

McKinney, G. (1941). Absorption of light by chlorophyll solutions. Journal of Biological Chemistry, 140:315-322.

Popovic, R.; Martinovic, B.; Vuckovic, M. and Rastovic, A. (1977). The effect of manganese and iron on photosynthetic activity. Biol. Vest., 25: 190.

Rippka, R.; Deruelles, J.; Waterbury, J.B.; Herdman, M. and Stanier, R.Y. (1979). Generic assignments, strain histories and properties of pure cultures of cyanobacteria. Journal of General Microbiology, 111: 1-61.

Schwarz, R. and Forchhammer, K. (2005). Acclimation of unicellular cyanobacteria to macronutrient deficiency: emergence of a complex network of cellular responses. Microbiology, 151: 2503-2514.

Egyptian J. of Phycol. Vol. 10, 2009 
Sekar, S. and Chandramohan, M. (2008). Phycobiliproteins as a commodity: trends in applied Research. Journal of Applied Phycology, 202: 113-136.

Singh, A. K. and Sherman, L. A. (2000). Identification of ironresponsive, differential gene expression in the cyanobacterium Synechocystis sp. strain PCC 6803 with a customized amplification library. Journal of Bacteriology, 182: 3536-3543.

Stanier, R. Y. and Cohen-Bazire, G. (1977). Phototrophic prokaryotes: the cyanobacteria. Annual Review of Microbiology, 31:225-274.

Umbriet, W. W.; Burris, R. H.; Stauffer, J. F.; Cohen, P. P.; Johnse, W.; Johanse, W. J.; Lee Page, G. A.; Potter, V. R. and Schneider, W.C. (1959). Monometric technique, a manual describing method, applicable to the study of describing metabolism, P. 239. Burgess publishing company.

Verstreate, D. R.; Storch, T. A. and Dunham, V. L. (1980).A comparison of the influence of iron on the growth and nitrate metabolism of Anabaena and Scenedesmus. Physiologia Plantarum, 50: 47-51.

Whitton, B. A. and Potts, M. (2000). The ecology of cyanobacteria. Their diversity in time and space. Freshwater blooms. pp, 149-194. Kluwer Academic Publishers. Dordrecht, The Netherlands. 


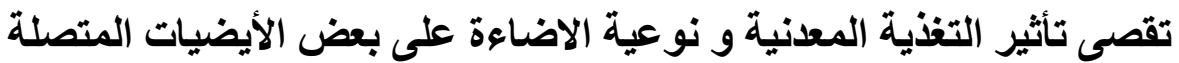

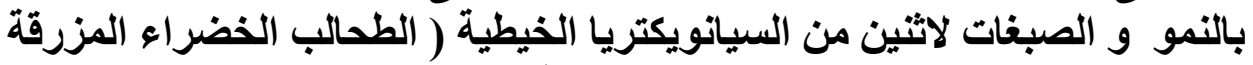

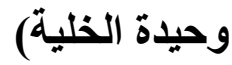

نيرمين عادل السمرى1، صفية محمد غازى 1،أبو الخير بلوى السيد²،محد مصطفى الفولى²، 1- أنسم النبات و المبكروبيولوجى، كلبة العلوم، جامعة حلوان. 2- ق قسم تكنولوجيا التسمبي، المركز القومى للبحوث، الدقى، القاهرة.

تم تحرى نأثثر التغذية المعدنية على الأيضيات المتصلة بالنمو و الصبغات لاثثين من السيانويكتريا

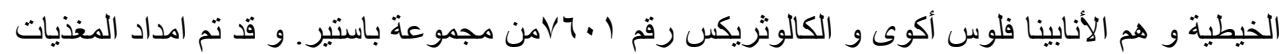

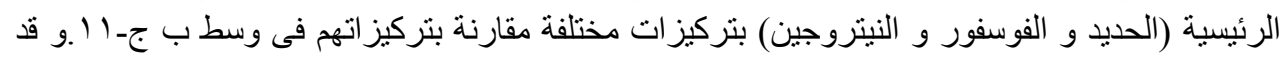

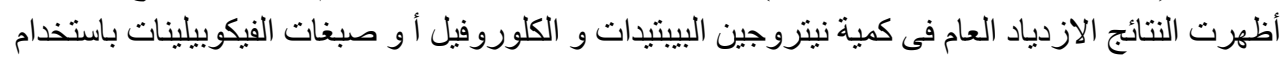

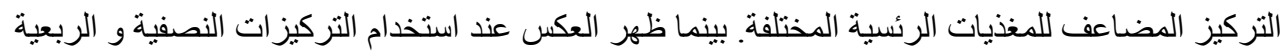

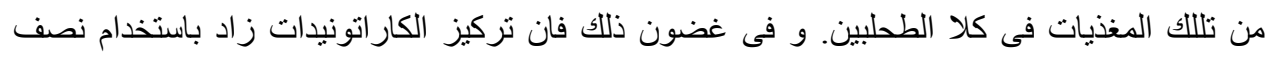

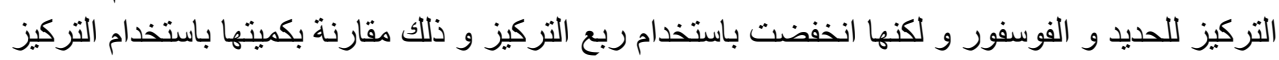

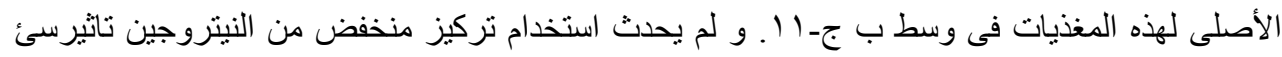

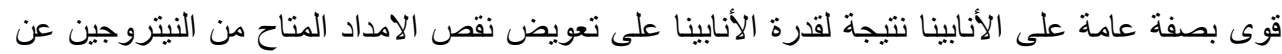

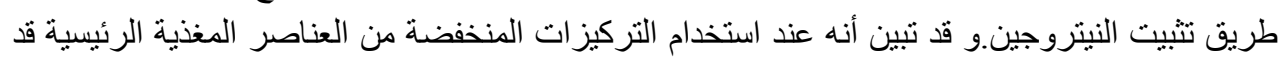

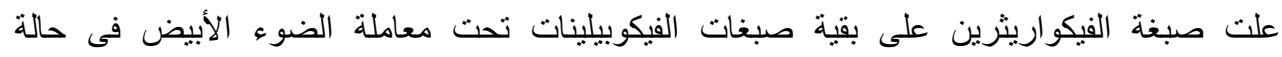

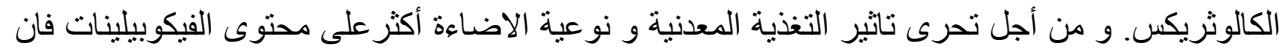

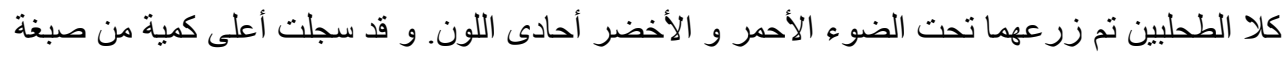

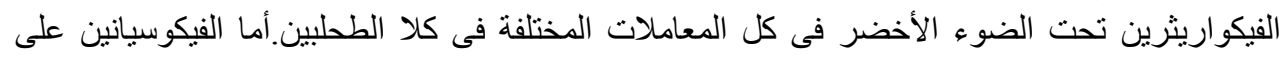

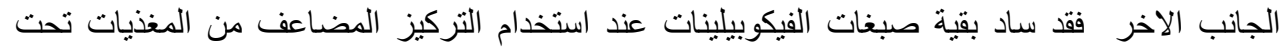

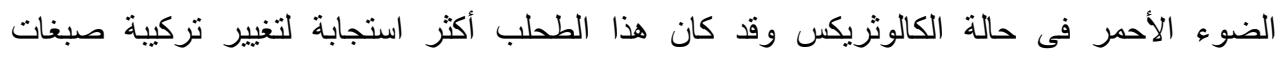

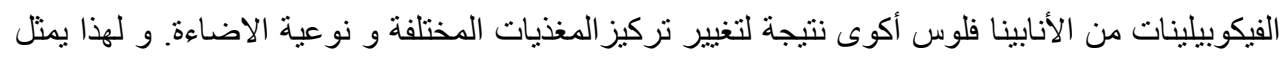

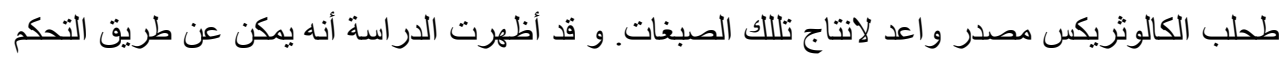

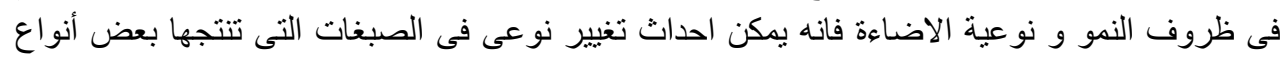

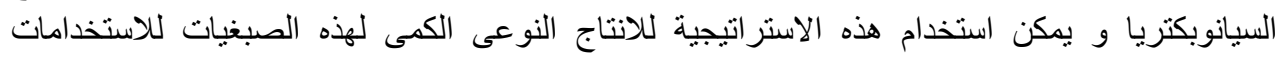

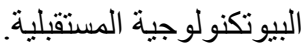

